\title{
Dendritic cells and the promise of antigen-specific therapy in rheumatoid arthritis
}

\author{
Ranjeny Thomas*
}

\begin{abstract}
Rheumatoid arthritis (RA) is a systemic inflammatory disease resulting from an autoimmune response to self-antigens, leading to inflammation of synovial tissue of joints and subsequent cartilage and bone erosion. Current disease-modifying anti-rheumatic drugs and biologic inhibitors of TNF, IL-6, T cells and $B$ cells block inflammation nonspecifically, which may lead to adverse effects, including infection. They do not generally induce long-term drug-free remission or restoration of immune tolerance to self-antigens, and lifelong treatment is usual. The development of antigen-specific strategies in RA has so far been limited by insufficient knowledge of autoantigens, of the autoimmune pathogenesis of RA and of the mechanisms of immune tolerance in man. Effective tolerance-inducing antigen-specific immunotherapeutic strategies hold promise of greater specificity, of lower toxicity and of a longer-term solution for controlling or even preventing RA. This paper reviews current understanding of autoantigens and their relationship to immunopathogenesis of $\mathrm{RA}$, and emerging therapeutics that aim to leverage normal tolerance mechanisms for implementation of antigen-specific therapy in RA.
\end{abstract}

\section{The therapeutic landscape in rheumatoid arthritis:} why are antigen-specific strategies needed?

Rheumatoid arthritis (RA) is a systemic inflammatory disease resulting from an autoimmune response to selfantigens, leading to inflammation of synovial tissue of joints and subsequent cartilage and bone erosion. Current treatments such as disease-modifying antirheumatic drugs and biologic inhibitors of TNF, IL-6, $\mathrm{T}$ cells and $\mathrm{B}$ cells have dramatically improved the quality

*Correspondence: Ranjeny.thomas@uq.edu.au

The University of Queensland Diamantina Institute, Translational Research Institute, Princess Alexandra Hospital, Brisbane, Queensland 4102, Australia of life for patients with RA. The progressive improvement in RA therapy that has occurred since the 1990s results from evidence that combination therapy is more effective than monotherapy, and that better RA outcomes occur with early therapeutic intervention and through the development and use of biologic therapies [1,2]. However, all current treatments are nonspecific suppressors of inflammatory pathways or of immune cells and may lead to adverse events. Side effects of current treatments range from peptic ulceration and hepatotoxicity to serious life-threatening infections and demyelinating disease.

Current drugs do not generally induce long-term drugfree remission or restoration of immune tolerance to selfantigens, and lifelong treatment is normally required. Moreover, approximately $30 \%$ of RA patients do not reach the desired treatment outcome - due to drug failure rates and/or toxicity [3]. For those patients experiencing serious adverse effects or treatment failure, disease progression may lead to deformity, disability and loss of productivity [4]. Furthermore, uncontrolled inflammation in RA is associated with a higher risk of atherosclerotic disease and cardiac complications with increased mortality [5]. Many of the current effective biologic drugs are very costly to produce in the quantities required to meet demand for the drug, placing a heavy burden on health authorities, patients and the community [6]. There is thus a recognised need for better treatments in RA. Ideally these treatments would target underlying disease pathogenesis with greater specificity, producing fewer side effects.

No therapeutic has yet achieved antigen specificity for controlling symptoms in RA. The development of such strategies has so far been limited by insufficient knowledge of RA autoantigens, of the autoimmune pathogenesis of RA and of the mechanisms of immune tolerance in man. On the contrary, excellent underpinning knowledge of inflammatory mediators of joint pathology, and the potent disease-modifying effect and the excellent revenues achieved by passive transfer of fully or partly humanised antibodies or soluble receptors targeting inflammatory pathways, have stimulated the development of many approaches over the past decades to reduce 
the inflammatory burden of RA. This development has improved the therapeutic options available to doctors and patients, and has captured a huge market in RA, predicted to be $\$ 12$ billion annually by 2017 . Effective tolerance-inducing antigen-specific immunotherapeutic strategies hold promise of greater specificity, of lower toxicity and of a longer-term solution to controlling or even preventing RA. After decades of disappointing results in this area, we are at last moving towards new therapeutic possibilities. This paper reviews current understanding of autoantigens and their relationship to immunopathogenesis of RA, and evolution of therapeutics developed to leverage normal tolerance mechanisms for implementation of antigen-specific therapy in RA.

\section{Self-reactivity to post-translationally modified antigens in RA and its implications for immunotherapy}

Autoreactivity towards a variety of self-proteins has been associated with the development and progression of RA. Some of the antigens described are joint-derived proteins, such as type II collagen and human cartilagederived glycoprotein HCgp39 [7]. Other antigens are stress-associated proteins, including grp78/BiP, which is an intracellular chaperone involved in endoplasmic reticulum stress and angiogenesis in proliferative RA synovial tissue $[8,9]$. Endoplasmic reticulum stress may be provoked by many factors, including proinflammatory cytokines, cell death, misfolding of proteins in the endoplasmic reticulum, and reactive oxygen species [10]. As a result of intracellular $\mathrm{Ca}^{2+}$ flux in these settings, deimination or citrullination of arginine is enhanced through activation of the peptidyl arginine deiminase enzymes [11]. Owing to the reduction in positive charge, citrullination substantially affects the protein structure and function, for example, of enzymes. These changes can affect the quality and stiffness of the extracellular membrane at inflamed sites [12].

Citrullination also plays a physiological role in apoptosis and epigenetics [13]. Citrullinated self-antigens have emerged as a major group of post-translationally modified autoantigens in RA. Approximately $70 \%$ of RA patient sera contain autoantibodies reactive to a variety of citrullinated peptide antigens (ACPA) [14]. These autoantigens include vimentin, fibrinogen, collagen type II, $\alpha$-enolase, clusterin, histones and peptidyl arginine deiminase-4 itself $[11,15,16]$. Citrullinated self-proteins are found in inflamed RA joints, but are not specific to RA. Post-translationally modified peptides probably represent an important means to diversify the repertoire of antigens (the immunopeptidome), and thus responding $\mathrm{T}$ cells, in response to inflammatory or stressful priming events such as infections. Smoking is an inducer of peptidyl arginine deiminase in the lung, and is likely to be a major trigger of post-translational modification of self-antigens in RA, including citrullination $[17,18]$. Stressinducing environmental agents such as smoking, obesity, and exposure to toxins such as silica and mineral oils promote expression of post-translationally modified neoantigens, which may trigger priming of autoreactive $\mathrm{T}$ cells in the peripheral repertoire of individuals genetically susceptible to RA.

The major histocompatibility complex (MHC) contributes about one-third of the genetic susceptibility to RA. Specific RA-associated human leukocyte antigen (HLA)DR alleles encode a conserved amino acid sequence in the HLA-DR antigen-binding groove, known as the shared epitope (SE) [19]. ACPA - reflecting autoreactivity to citrullinated self-antigens - are much more likely to occur in patients with the HLA-DR SE [20]. Polymorphisms at amino acid positions 11,71 and 74 of the DR $\beta$ chain and single amino acid associations in the peptide binding groove of HLA-B (position 9) and HLA-DP $\beta 1$ (position 9) were found almost completely to explain the MHC association with seropositive RA [21]. Amino acids at positions 71 and 74 form part of the fourth anchoring pocket (P4 of HLA-DR). The encoded amino acid at position 71 is positively charged, and therefore preferentially binds nonpolar amino acids, including citrulline, but not the unmodified positively-charged arginine [21].

It has been proposed that tightly-bound posttranslationally modified peptide antigens are available for presentation to the T-cell antigenic receptor in the periphery, but not for negative selection in the thymus [22]. Deletion of autoreactive $\mathrm{T}$ cells in the thymus depends on strong T-cell receptor (TCR) recognition and signalling by peptide-MHC complexes, which would not occur with nonbinding native self-peptides. Peptides modified by a variety of post-translational modifications, including citrullination, transglutamination and oxidation, are implicated in a number of autoimmune diseases, including multiple sclerosis, type 1 diabetes and coeliac disease $[23,24]$. Post-translational modifications are likely to represent a general mechanism for immune priming to neoself-antigens for which $\mathrm{T}$ cells potentially reactive with the native self-antigen were poorly deleted in the thymus, if at all, due to insufficient binding strength of the native peptide to the susceptibility HLA allele.

Following the initial elucidation of citrullinated T-cell epitopes that bound strongly to HLA-SE molecules, and which stimulated T-cell responses and inflammatory arthritis in HLA-DR4 transgenic mice [25,26], we and others demonstrated citrullinated autoantigen-specific T-cell autoimmunity in RA patients carrying HLA susceptibility alleles [27-29]. We found that proinflammatory cytokines were secreted by peripheral blood (PB) $\mathrm{CD}^{+} \mathrm{T}$ cells of RA patients and healthy controls, in response to citrullinated but not unmodified peptides in 
the context of the HLA-SE sequence. RA patient T cells secreted a broader range of cytokines than healthy control $\mathrm{T}$ cells. Of the peptides tested, citrullinated aggrecan was most immunogenic [27]. Together, these studies indicate that citrulline does indeed confer the capacity of self-peptides to bind the SE, and that $\mathrm{PB}$ $\mathrm{T}$ cells from HLA-SE-positive individuals respond to these peptides in vitro.

\section{Antigen-specific tolerising immunotherapy and dendritic cells}

Loss of tolerance to self-antigens is a critical component in the pathogenesis of autoimmunity. Both central (thymic) and peripheral tolerance mechanisms exist for the control of self-reactive T cells. Active mechanisms of peripheral tolerance include deletion of self-reactive cells after antigen recognition and regulation of self-reactive effector responses by specialised populations of regulatory $\mathrm{T}$ cells (Tregs). These mechanisms maintain the tolerant state in order to avoid autoimmune disease long term. Several T-cell and natural killer T-cell populations with the ability to inhibit the response of effector $\mathrm{T}$ cells have been described.

Autoreactivity of $\mathrm{T}$ cells and $\mathrm{B}$ cells towards selfantigens associated with the development and progression of RA presents an opportunity for antigen-specific tolerising immunotherapy to induce antigen-specific regulatory cells, including Tregs. Attempts to harness antigen-specific tolerance to modify the autoimmune response in RA have been made since the early 1990s. These include oral tolerance, TCR peptide vaccination and HLA-DR peptide vaccination. Antigens used in oral tolerance trials include type II bovine or chicken collagen, HCgp39, dnaJp1, and lyophilised Escherichia coli extract. Oral tolerance relies on presentation of the relevant peptides by constitutive mucosal dendritic cells (DCs), with the capacity to regulate pathogenic $\mathrm{T}$ cells by deletion, immune deviation or through Treg-mediated suppression (Figure 1a). While some evidence for induction of regulatory populations or immune deviation to less pathogenic T-cell cytokines was produced, efficacy of oral autoantigens was limited [30-32].

Tolerogenic antigen presentation after mucosal delivery by mucosal DCs, however, may be unreliable for several reasons. First, there may be a small tolerising antigen dose window, and disease flares may occur due to antigen sensitisation of the immune system [33]. This is a welldescribed side effect of specific immunotherapy for allergic desensitisation, which relies on immune deviation and induction of Tregs to crude allergen preparations delivered to the skin or sublingually. Second, the capacity of Tregs to suppress pathologic cytokine production by effector $\mathrm{T}$ cells is dysfunctional and DCs are activated at inflammatory sites in RA, and therefore unpredictable effects may occur without control over the antigen presenting cells at mucosal sites [34-37]. Third, the gastrointestinal tract of RA patients may be colonised with distinct microflora, including oral Porphyromonas gingivalis, which may themselves promote inflammatory arthritis [38]. Finally, effector-memory autoreactive $\mathrm{T}$ cells - present in RA synovium - are known to be more resistant to tolerance mechanisms than naïve T cells $[39,40]$.

Alternatively, DCs presenting autoantigen in vitro or in vivo could be modified to promote their capacity to delete antigen-specific $\mathrm{T}$ cells or to induce antigenspecific Tregs in vivo: so-called tolerising DCs (Figure 1b). Such DCs, when delivered with appropriate autoantigens, should afford greater control over the outcome of antigen-specific immunotherapy through the induction of Tregs. If this strategy were effective, antigen-specific suppression of pathogenic T cells in RA patients would avoid generalised immune suppression, focusing tolerance mechanisms on relevant autoantigens. This effect might be anticipated to restore tolerance towards RA self-antigens with low toxicity, suitable for suppression of early disease or for prevention in individuals at risk.

\section{Translation of tolerising immunotherapeutic approaches in RA and other autoimmune and inflammatory diseases}

Oral tolerance

In animal models, orally administered type II collagen suppressed collagen-induced arthritis as well as adjuvant arthritis - the latter presumably through secretion of anti-inflammatory cytokines by bystander $\mathrm{T}$ cells, or linked suppression through induction of collagen type IIspecific regulatory cells and their migration to the joint [41-43]. Oral mycobacterial heat shock protein 65 or human gp39 also attenuated collagen-induced arthritis and adjuvant arthritis $[44,45]$. Oral chicken or bovine type II collagen was safe when administered to patients with RA. While some clinical improvement was noted in open-labelled studies, placebo-controlled trials found no statistically significant improvement in collagen-fed patients, including among patients with early RA [30,46-48]. Oral human gp39 was also trialled by two companies, but with little evidence of efficacy [49]. Oral lyophilised E. coli extract contains several bacterial heat shock proteins with immunomodulatory properties. The extract's clinical efficacy was equivalent to D-penicillamine in a placebo-controlled trial [50]. However, this extract is more likely to be a nonspecific immunomodulator than to induce antigen-specific tolerance.

Oral dnaJp1 was trialled in phase I and phase II clinical trials in RA. This bacterial heat shock protein sequence has been proposed to be cross-reactive with corresponding self-peptides in RA because it is homologous with the 
(a)

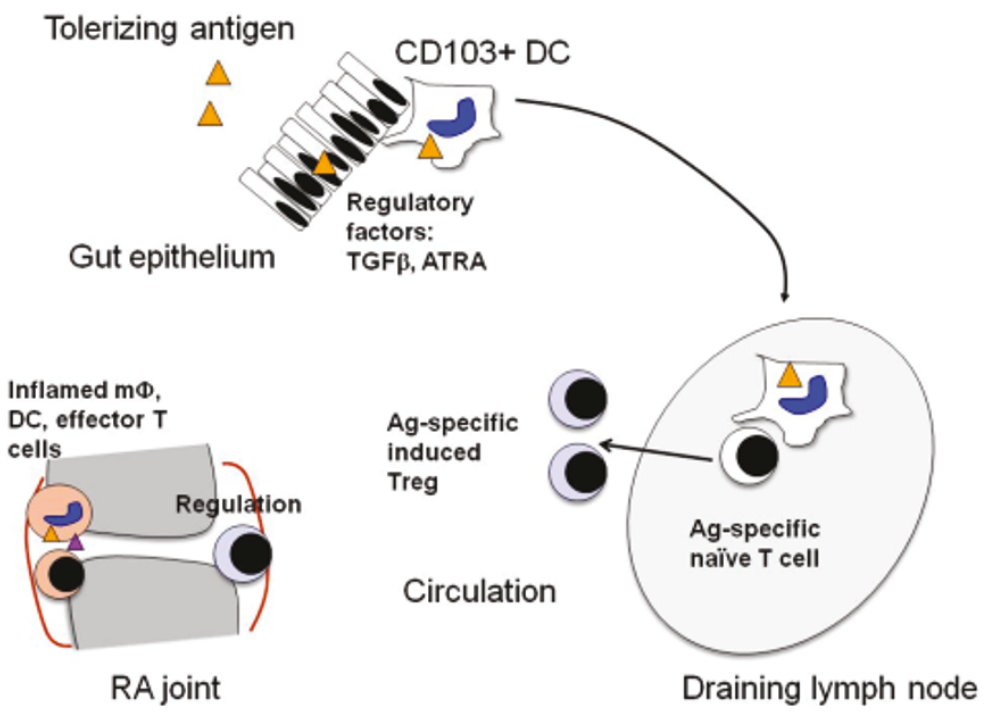

(b)

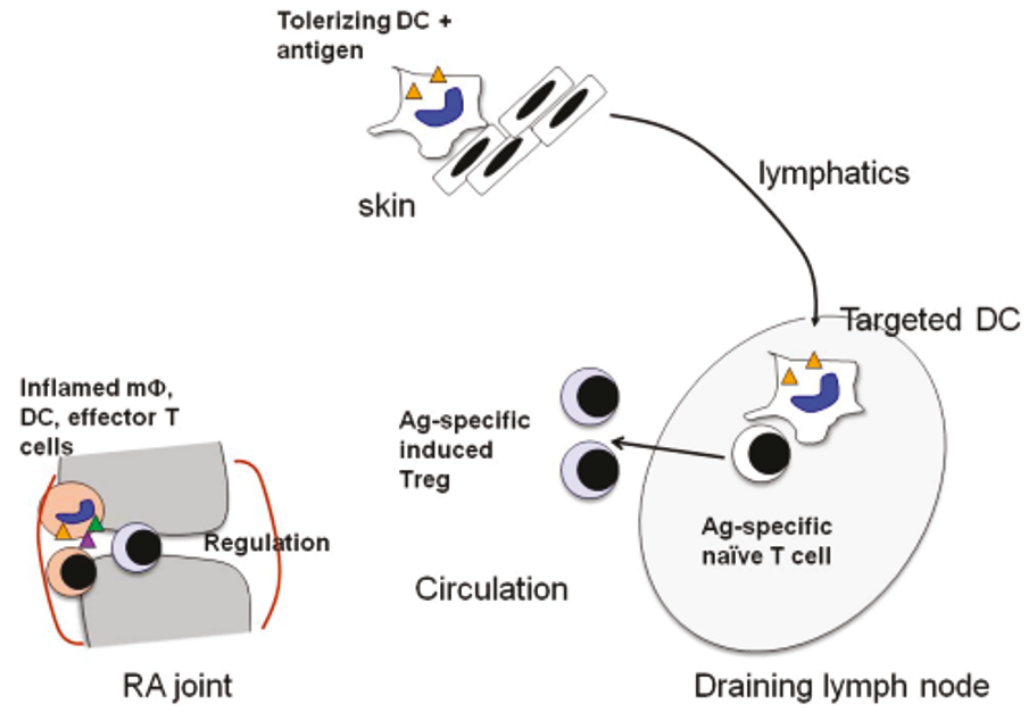

Tolerizing DC +

antigen

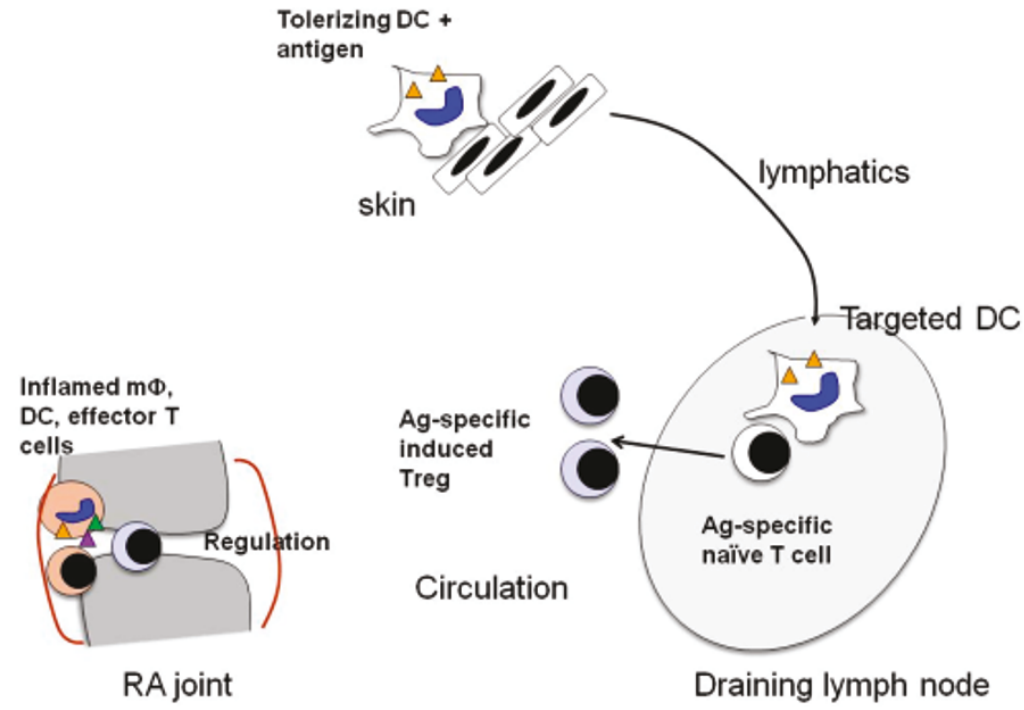

skin

Figure 1. Principles underlying the induction of antigen-specific regulation. (a) Mucosal tolerance. Rheumatoid arthritis (RA) self-antigen is delivered to the mucosal immune system by the oral or nasal route. If taken up and presented by the appropriate CD103+ dendritic cells (DCs), which reside in the transforming growth factor-beta (TGF $\beta$ )-rich gut lamina propria and draining lymph nodes, antigen-specific regulatory $T$ cells (Tregs) can be induced in the presence of all-trans retinoic acid (ATRA). These Tregs should suppress RA self-antigen-specific immune responses in the joint. (b) Tolerising DC immunotherapy. DCs with tolerising capacity are generated from peripheral blood monocytes in vitro in the presence of inhibitory drugs to prevent DC activation after contact with Toll-like receptor ligands or cytokines. The DCs are then exposed to RA self-antigen and washed. The antigen-presenting DCs are injected and should induce antigen-specific Tregs in draining lymph nodes. These Tregs should suppress RA self-antigen-specific immune responses in the joint. Tolerizing DC + antigen may also be injected into joints, venous blood or lymphatics. Ag, antigen.

HLA-DR SE sequence. Oral dnaJp1 had an excellent safety profile and demonstrated immune modulatory effects. Whereas patients generally made Th1-type T-cell cytokine and proliferative responses to dnaJp1 at baseline, dnaJ-specific proliferation and IFNY decreased and IL-4 and IL-10 increased after the treatment [51]. In a placebo-controlled phase II clinical trial, the dnaJp1treated group showed statistically significant improvement in American College of Rheumatology scores after 6 months of daily oral dnaJp1 peptide, associated with increased expression of regulatory molecules and decreased secretion of TNF in PB [52].

T-cell receptors in RA and T-cell receptor peptide vaccination Diversity is generated through gene rearrangement within the Variable (V) domains of the TCR; namely, the 
$\mathrm{V}$ and Junction gene segments of the $\mathrm{V} \alpha$ chain, and the $\mathrm{V}$, Diversity and Junction gene segments of the $V \beta$ chain. Junctional diversity also occurs through random insertions and deletions at these V-Diversity-Junction regions. This diversity is manifested in the complementarity determining regions (CDRs) of the TCR, which directly interact with the peptides presented by MHC class II (pMHC-II). Despite the potential breadth of the TCR repertoire, there are many examples in anti-viral immunity of biased or restricted $\mathrm{V} \alpha$ or $\mathrm{V} \beta$ usage and CDR3 sequences [53]. This effect is known as a public immune response, in which individuals share a similar Tcell repertoire to a given HLA-restricted peptide antigen. Although early studies suggested bias in the T-cell repertoire in RA, their interpretation is limited by the techniques used [54-56]. More recently, using real-time PCR, biased V $\beta$ usage and CDR3 sequences were shown in the synovial fluid T-cell repertoire of RA patients, particularly in patients with HLA-DRB1*0405 [57]. Furthermore, evidence of T-cell clonal expansion in synovial tissue of early RA patients was shown by $V \beta$ TCR sequencing. While the most expanded clones were shared between different joints, CDR3 sequences were not shared between patients [58]. This study was insufficiently sensitive to address the question of public TCR sequences, however, because HLA-DRB1*04 alleles were not subtyped to allow comparison of sequences associated with a single MHC allele.

An alternative approach to antigen-specific vaccination is based on evidence from animal models, including arthritis and experimental allergic encephalomyelitis, that antigen-specific T-cell lines or clones prevent priming of autoimmune diseases [59]. The mechanism of this phenomenon was in part related to induction of Tregs reactive with the CDR3 regions of the autoreactive TCRs [60]. The approach has been pursued in a number of trials in multiple sclerosis patients. Although modest benefits have been reported, these are all open-labelled studies (reviewed in [61]). Based on some early work suggesting that $V \beta 3, V \beta 14$ and $V \beta 17$ determinants were dominant in RA, a trial was undertaken of $\mathrm{V} \beta 3, \mathrm{~V} \beta 14$ and V $\beta 17$ peptides emulsified in incomplete Freund's adjuvant [62]. Vaccination with a limited number of peptides on a population basis assumes the presence of public TCR determinants. Given that patients were not recruited on the basis of a defined HLA-DR allele (no HLA typing was reported), the clinical effects of the peptide vaccination were predictably small [62].

\section{$\mathrm{CD} 4{ }^{+} \mathrm{CD} 25^{+}$natural regulatory $\mathrm{T}$ cells}

Mice thymectomised on day 3 after birth develop a syndrome of organ-specific autoimmune disease, including oophoritis, gastritis, and/or thyroiditis. The mice can be rescued from illness by transfer of $\mathrm{CD} 4{ }^{+} \mathrm{CD} 25^{+} \mathrm{T}$ cells from a syngeneic adult spleen, and depletion of this population from nonthymectomised mice leads to a similar spectrum of autoimmune disease [63-66]. Since these discoveries were made in the 1960s and 1970s, $\mathrm{CD} 4{ }^{+} \mathrm{CD} 25^{+}$Tregs (known as natural Tregs), which express the transcription factor FoxP3, have been well characterised as a thymic-derived suppressor or regulatory population that regulates effector T-cell proliferative and cytokine responses to self-antigens and foreign antigens, innate inflammatory cells and DCs [67-69]. Owing to their high expression of the high affinity IL-2 receptor CD25, they survive and expand in response to IL-2 and anti-CD3/CD28 activation in vitro and in vivo [70]. Bulk Tregs expanded ex vivo or in vivo (using immature DCs), when transferred to mice with collageninduced arthritis, slowed the progression of disease in an antigen nonspecific manner, through local effects on the joints [71,72]. Autoantigen-specific TCR-transgenic Tregs expanded using DCs, peptide and IL-2 similarly restored normoglycemia to mice with type 1 diabetes [73]. Transfer of bulk IL-2-expanded and CD3/CD28-expanded Tregs [74] has been translated to patients with type 1 diabetes in a clinical trial, currently underway.

\section{Induced $\mathrm{CD4}^{+}$regulatory $\mathrm{T}$ cells including $\mathrm{T}$ regulatory type 1 cells}

T regulatory type $1(\operatorname{Tr} 1)$ cells can be induced in vitro and in vivo in the periphery by DCs expressing high levels of IL-10 and low IL-12 [75,76]. Tr1 cells secrete high levels of IL-10 and moderate levels of transforming growth factor-beta, granulocyte-macrophage colony-stimulating factor, IL-5 and IFNy, but little IL-4 [77]. A review article describing a phase I clinical trial of IL-10-induced donor lymphocytes in patients with high-risk hematopoietic malignancies transplanted with CD34 ${ }^{+}$hemopoietic stem cells from haploidentical donors reported mild acute and no chronic graft-versus-host disease in patients receiving Tr1 cells [78].

Extra-thymic antigen-specific FoxP3 ${ }^{+}$Treg induction or conversion from $\mathrm{CD}^{+}{ }^{+} \mathrm{FoxP} 3^{-} \mathrm{CD} 25^{-}$naïve $\mathrm{T}$ cells has been demonstrated in gut-associated lymphoid tissue and mesenteric draining lymph nodes. All-trans retinoic acid is a key regulator promoting this conversion, in the presence of gut-derived DCs, transforming growth factor-beta and antigen [79,80] (Figure 1a). The CD103+ DC subset, found in gut and mesenteric lymph node, plays a specialised role in Treg conversion, as expression of aldh1a2 - a retinal dehydrogenase involved in the conversion of retinal (vitamin A) into all-trans retinoic acid - is increased in this subset [81,82]. All-trans retinoic acid promotes the generation of $\mathrm{FoxP}^{+}$Treg in the presence of anti-CD3 and in the absence of antigenpresenting cells, indicating that all-trans retinoic acid signals CD25- Treg precursors through a retinoic acid 
receptor, promoting FoxP3 expression in the presence of transforming growth factor-beta [83-85].

\section{Tolerising dendritic cell immunotherapy}

Tr1 Tregs can be induced in vivo by NF-kB or CD40deficient DCs. NF- $\mathrm{kB}$ is a transcription factor family comprising five subunits involved in two pathways: the classical pathway (including p65 transcriptional activity) plays an important role in innate immunity, and the alternate pathway (including RelB activity) plays a role in immune tolerance and adaptive immune activation $[86,87]$. RelB activity is required for myeloid DC differentiation and function [88-90]. We showed that RelB regulates antigen-presenting cell function through regulation of CD40 and MHC molecule expression [91,92]. Antigenexposed myeloid DCs, in which RelB function is inhibited, prevent priming of immunity and suppress a previously-primed immune response. RelB activity thus determines the consequences of presentation of antigen by myeloid DCs. Induction of suppression was specific for the antigen to which DCs had been exposed. This suppression resulted from induction in draining lymph node and spleen of antigen-specific Tregs resembling Tr1 cells, which were CD4+IL- $10^{+}$. CD4 ${ }^{+}$splenic $\mathrm{T}$ cells from tolerant animals transferred antigen-specific tolerance to primed recipients. The DCs therefore induced an active infectious process of antigen-specific regulation [93].

We and others have developed other means to block production or nuclear translocation of RelB and other NF- $\kappa B$ family members in DCs, including anti-sense and soluble inhibitors, and the resulting modified DCs were consistently tolerogenic through induction of Tregs $[91,94,95]$. Induction of tolerance in response to one antigen does not simultaneously produce tolerance to antigens expressed elsewhere in the body. This property allows for exquisite specificity in tailoring therapeutic interventions to specific pathogenic antigens without global immune suppression. Given the potential for development of antigen-specific autoimmune immunotherapy using DCs treated with soluble inhibitors of NF- $\kappa B$, such as Bay11-7082 (Bay-DCs) [94], we translated this concept to a phase I clinical trial of autologous BayDCs exposed to citrullinated peptides in HLA-DR$\mathrm{SE}^{+} \mathrm{ACPA}^{+} \mathrm{RA}$ patients. In vitro studies of human blood Bay-DCs demonstrated similar phenotype and in vitro functional capacity to murine Bay-DCs [96]. Preclinical experiments in the mBSA antigen-induced arthritis model demonstrated suppression of established arthritis, equivalent to treatment with soluble TNF receptor, in mice treated with a single dose of Bay-DCs exposed to mBSA but not to control antigen. Skin-test reactivity to mBSA was simultaneously reduced and anti-mBSA antibodies were switched from Th1 to Th2 and regulatory isotypes, including $\operatorname{IgG1}$ and IgA but not IgE [97].
Preliminary clinical data demonstrate the feasibility, safety, systemic and clinical effects of a single intradermal administration of Bay-DCs exposed to citrullinated peptides in RA patients [98].

A number of other approaches have been used to generate tolerising human or murine DCs from PB or bone marrow precursors, based on suppression of DC activation in response to inflammatory stimuli [99]. DCs are commonly generated from precursors, and then incubated with pathogen-associated molecular pattern activators, such as lipopolysaccharide or monophosphoryl lipid A, in the presence of NF-kB inhibitors, such as vitamin D3, glucocorticoids or IL-10, or the mammalian target inhibitor rapamycin. Alternatively, DCs are incubated with TNF, IL-6 or low-dose endotoxin to produce so-called semi-mature or tolerant DCs [100104]. A phase 0 clinical trial of dexamethasone, vitamin D3 and monophosphoryl lipid A-modulated autologous DCs in RA patients is in progress [104], and interesting phase 1 safety, immunological and clinical data from a clinical trial of modified autologous DCs in long-standing type 1 diabetes patients were recently published [105].

\section{Conclusions and challenges for the field}

Restoration of tolerance to self-antigens is currently an exciting field. After many years in the doldrums, considerable progress has been made to understand how T-cell regulation occurs and how to control antigenpresenting cells for induction of tolerance. Moreover, persistent efforts to translate cellular therapeutic approaches from mouse models have seen the commencement and early reporting of data from proof-of-concept clinical trials of both tolerising DCs and Treg transfer in autoimmune disease and graft-versus-host disease.

There are several key challenges. First, personalised autologous cell therapy is extremely challenging to develop for widespread clinical use. A major challenge pertains to the regulatory requirements for standardisation, sterility and quality control of cell therapies. If used to obtain PB cells, leukapheresis is associated with a degree of morbidity, and is logistically difficult in many centres. There are also difficulties designing protocols with adequate control groups, and as trials continue in this area there will be difficulties comparing results from individual small trials in which varying cell culture protocols or antigen preparations have been used. The cost of carrying out autologous cell therapy trials is also a major impediment to the scale-up required for laterphase trials. Furthermore, this cost may be justifiable in cancer settings where therapeutic options are few, but this is more difficult in RA.

Clinical trials of various forms of antigen-loaded tolerising DCs or antigen-specific Tregs will therefore be useful to demonstrate proof-of-concept for RA 
immunotherapy. However, the future challenge is to translate such a concept to a therapeutic that is more broadly applicable than adoptive transfer of autologous cell products. To achieve this challenge, we formulated liposomes to target antigen and NF- $\mathrm{kB}$ inhibitor to DCs in situ. Curcumin, a natural lipophilic NF- $\mathrm{kB}$ inhibitor and antioxidant, was incorporated into $400 \mathrm{~nm}$ egg phosphatidyl choline liposome particles, which were also loaded with antigenic proteins or peptides. The liposomes encapsulated antigens and lipophilic NF- $\mathrm{kB}$ inhibitors stably and efficiently. We injected loaded liposomes into mice with antigen-induced inflammatory arthritis. When delivered intravenously or subcutaneously, the liposomes targeted antigen-presenting cells including DCs, macrophages and B cells in situ, suppressing responsiveness to NF- $\kappa \mathrm{B}$ and inducing antigen-specific Tregs. This regulatory mechanism suppressed effector T-cell responses and the clinical signs of full-blown antigen-induced arthritis [106]. These results demonstrate that DC function can be effectively altered by NF-kB inhibitors using in vivo targeting.

The second major challenge is that the diversity of autoantigens in RA raises questions about which one(s) to target, and whether targeting a single autoantigen would fail due to subsequent epitope-spreading in autoreactive recipients. The mechanism of tolerance induction is relevant in this regard. Regulatory or suppressive T-cell responses targeted to specific antigens (antigenspecific Tregs) can simultaneously suppress bystander responses in the same location [107]. One might therefore anticipate that joint inflammatory responses might be suppressed by arthritogenic antigen-specific Tregs of a single specificity even if autoreactivity to multiple autoantigens were present. On the contrary, tolerance elicited by deletion or anergy of antigen-specific $\mathrm{T}$ cells would be particularly prone to failure, when autoreactive $\mathrm{T}$ cells of new autoantigenic specificities are induced by epitope spreading [108]. This issue brings perhaps the key challenge to the fore: the need for effective reagents to detect and measure the responses of autoantigen-specific $\mathrm{CD} 4{ }^{+} \mathrm{T}$ cells in RA.

The development of multimeric pMHC complexes has revolutionised the detection of antigen-specific $\mathrm{T}$ cells in mice and humans. Tetramer or multimer reagents consist of four or more soluble MHC molecules each loaded with a single peptide bound to streptavidin and coupled to a fluorescent marker. By mimicking pMHC complexes normally expressed by antigen-presenting cells, tetramers bind to the receptors of antigen-specific $\mathrm{T}$ cells and allow them to be enumerated and functionally characterised or expanded. pMHC-I tetramers have greatly enhanced understanding of the CD8 T-cell response in viral infections and cancer. However, stable and specific pMHC-II tetramer production is technically more challenging. Nevertheless this technology has recently improved for the production of pMHC-II (human HLADR) tetramers, facilitating the understanding of autoimmune responses [109]. Low-frequency antigen-specific T-cell populations have been identified in the blood of patients with coeliac disease and type 1 diabetes, and analysis of the TCR repertoire can greatly enhance understanding of the way that post-translationally modified peptides may be driving autoimmune disease processes [110]. Although it is clear that ACPA are highly specific for RA, the understanding of T-cell responses towards such autoantigens in RA is still rudimentary. Ongoing development of a toolkit of more sensitive pMHC-II tetramer biomarkers, so that autoantigenspecific T-cell responses can be monitored during clinical trials of antigen-specific therapy, is clearly essential for ongoing development in this field.

ACPA may predate the onset of clinical RA by up to 15 years [111]. Addition of assays for rheumatoid factor isotypes and for multiple serum cytokines and chemokines has been shown to enhance the specificity for prediction of RA disease onset [16,112]. These advances in biomarkers for prediction of future disease, as well as evidence that treatment of patients with undifferentiated arthritis may delay the diagnosis of RA, suggest that preventive approaches might eventually be feasible in genetically at-risk individuals or families [113,114]. Clearly, demonstration of safety and efficacy using antigen-specific immunotherapeutic strategies in patients with early established RA would be an important first step along that road.

\section{Abbreviations}

ACPA, anti-citrullinated protein antibodies; $C D R$, complementarity determining region; DC, dendritic cell; HLA, human leukocyte antigen; IFN, interferon; IL, interleukin; MHC, major histocompatibility complex; NF, nuclear factor; $\mathrm{PB}$, peripheral blood; $\mathrm{PCR}$, polymerase chain reaction; $\mathrm{PMHC}$, peptides presented by MHC; RA, rheumatoid arthritis; SE, shared epitope; TCR, T-cell receptor; Th, T-helper type; TNF, tumour necroisis factor; $\operatorname{Tr} 1, T$ regulatory type $1 ;$ Treg, regulatory $T$ cell; $V$, variable gene segment.

\section{Competing interests}

RT has filed a provisional patent surrounding technology for targeting DCs for antigen-specific tolerance, and is a director of a spin-off company that is commercialising vaccines which target DCs to suppress autoimmune diseases.

\section{Acknowledgements}

The author thanks Jamie Rossjohn and Hugh Reid, Monash University, Melbourne, Australia for helpful discussions. The author is supported by Arthritis Queensland and an Australian Research Council Future Fellowship.

\section{Published: 4 February 2013}

\section{References}

1. O'Dell JR, Haire CE, Erikson N, Drymalski W, Palmer W, Eckhoff PJ, Garwood V, Maloley P, Klassen LW, Wees S, Klein H, Moore GF: Treatment of rheumatoid arthritis with methotrexate alone, sulfasalazine and hydroxychloroquine, or a combination of all three medications. NEngl J Med 1996, 334:1287-1291.

2. Smolen JS, Landewé R, Breedveld FC, Dougados M, Emery P, Gaujoux-Viala C, Gorter S, Knevel R, Nam J, Schoels M, Aletaha D, Buch M, Gossec L, Huizinga T, 
Bijlsma JWJW, Burmester G, Combe B, Cutolo M, Gabay C, Gomez-Reino J, Kouloumas M, Kvien TK, Martin-Mola E, McInnes I, Pavelka K, van Riel P, Scholte M, Scott DL, Sokka T, Valesini G, et al:: EULAR recommendations for the management of rheumatoid arthritis with synthetic and biological disease-modifying antirheumatic drugs. Ann Rheum Dis 2010, 69:964-975.

3. Emery P, Dorner T: Optimising treatment in rheumatoid arthritis: a review of potential biological markers of response. Ann Rheum Dis 2011 , 70:2063-2070.

4. Breedveld FC, Han C, Bala M, van der Heijde D, Baker D, Kavanaugh AF, Main RN, Lipsky PE: Association between baseline radiographic damage and improvement in physical function after treatment of patients with rheumatoid arthritis. Ann Rheum Dis 2005, 64:52-55.

5. Maradit-Kremers H, Nicola PJ, Crowson CS, Ballman KV, Gabriel SE: Cardiovascular death in rheumatoid arthritis: a population-based study. Arthritis Rheum 2005, 52:722-732.

6. Fautrel B, Verstappen SMM, Boonen A: Economic consequences and potential benefits. Best Pract Res Clin Rheumatol 2011, 25:607-624.

7. Tsark EC, Wang W, Teng YC, Arkfeld D, Dodge GR, Kovats S: Differential MHC class II-mediated presentation of rheumatoid arthritis autoantigens by human dendritic cells and macrophages. J Immuno/ 2002, 169:6625-6633.

8. Blass S, Union A, Raymackers J, Schumann F, Ungethum U, Muller-Steinbach $\mathrm{S}$, De Keyser F, Engel JM, Burmester GR: The stress protein BiP is overexpressed and is a major $B$ and $T$ cell target in rheumatoid arthritis. Arthritis Rheum 2001, 44:761-771.

9. Yoo S-A, You S, Yoon H-J, Kim D-H, Kim H-S, Lee K, Ahn JH, Hwang D, Lee AS, Kim K-J, Park Y-J, Cho C-S, Kim W-U: A novel pathogenic role of the ER chaperone GRP78/BiP in rheumatoid arthritis. J Exp Med 2012, 209:871-886.

10. Hasnain SZ, Lourie R, Das I, Chen ACH, McGuckin MA: The interplay between endoplasmic reticulum stress and inflammation. Immuno/ Cell Bio/ 2012, 90:260-270

11. Anzilotti C, Pratesi F, Tommasi C, Migliorini P: Peptidylarginine deiminase 4 and citrullination in health and disease. Autoimmun Rev 2010, 9:158-160.

12. Leeming DJ, Bay-Jensen AC, Vassiliadis E, Larsen MR, Henriksen K, Karsdal MA: Post-translational modifications of the extracellular matrix are key events in cancer progression: opportunities for biochemical marker development. Biomarkers 2011, 16:193-205.

13. Tanikawa C, Espinosa M, Suzuki A, Masuda K, Yamamoto K, Tsuchiya E, Ueda K, Daigo Y, Nakamura Y, Matsuda K: Regulation of histone modification and chromatin structure by the p53-PADI4 pathway. Nat Commun 2012, 3:676

14. Vossenaar $E R$, Van Venrooij WJ: Citrullinated proteins: sparks that may ignite the fire in rheumatoid arthritis. Arthritis Res Ther 2004, 6:107-111.

15. Masson-Bessiere C, Sebbag M, Girbal-Neuhauser E, Nogueira L, Vincent C, Senshu T, Serre G: The major synovial targets of the rheumatoid arthritisspecific antifilaggrin autoantibodies are deiminated forms of the alphaand beta-chains of fibrin. J Immunol 2001, 166:4177-4184.

16. Sokolove J, Bromberg R, Deane KD, Lahey LJ, Derber LA, Chandra PE, Edison JD, Gilliland WR, Tibshirani RJ, Norris JM, Holers VM, Robinson WH: Autoantibody epitope spreading in the pre-clinical phase predicts progression to rheumatoid arthritis. PLoS One 2012, 7:e35296.

17. Makrygiannakis D, Hermansson M, Ulfgren A-K, Nicholas AP, Zendman AJW, Eklund A, Grunewald J, Skold CM, Klareskog L, Catrina Al: Smoking increases peptidylarginine deiminase 2 enzyme expression in human lungs and increases citrullination in BAL cells. Ann Rheum Dis 2008, 67:1488-1492.

18. Klareskog L, Stolt P, Lundberg K, Kallberg H, Bengtsson C, Grunewald J, Ronnelid J, Harris HE, Ulfgren AK, Rantapaa-Dahlqvist S, Eklund A, Padyukov L, Alfredsson L: A new model for an etiology of rheumatoid arthritis: smoking may trigger HLA-DR (shared epitope)-restricted immune reactions to autoantigens modified by citrullination. Arthritis Rheum 2006, 54:38-46.

19. Gregersen PK, Silver J, Winchester RJ: The shared epitope hypothesis: an approach to understanding the molecular genetics of suseptibility to rheumatoid arthritis. Arthritis Rheum 1987, 30:1205-1213.

20. van der Helm-van Mil AHM, Verpoort KN, le Cessie S, Huizinga TWJ, de Vries RRP, Toes REM: The HLA-DRB1 shared epitope alleles differ in the interaction with smoking and predisposition to antibodies to cyclic citrullinated peptide. Arthritis Rheum 2007, 56:425-432.

21. Raychaudhuri S, Sandor C, Stahl EA, Freudenberg J, Lee H-S, Jia X, Alfredsson L, Padyukov L, Klareskog L, Worthington J, Siminovitch KA, Bae S-C, Plenge RM, Gregersen PK, de Bakker PIW: Five amino acids in three HLA proteins explain most of the association between $\mathrm{MHC}$ and seropositive rheumatoid arthritis. Nat Genet 2012, 44:291-296

22. Thomas R, Turner M, Cope AP: High avidity autoreactive T cells with a low signalling capacity through the T-cell receptor: central to rheumatoid arthritis pathogenesis? Arthritis Res Ther 2008, 10:210.

23. Kim C-Y, Quarsten H, Bergseng E, Khosla C, Sollid LM: Structural basis for HLA-DQ2-mediated presentation of gluten epitopes in celiac disease. Proc Natl Acad Sci U S A 2004, 101:4175-4179.

24. Mannering SI, Harrison LC, Williamson NA, Morris JS, Thearle DJ, Jensen KP, Kay TW, Rossjohn J, Falk BA, Nepom GT, Purcell AW: The insulin A-chain epitope recognized by human $T$ cells is posttranslationally modified. J Exp Med 2005, 202:1191-1197.

25. Hill JA, Bell DA, Brintnell W, Yue D, Wehrli B, Jevnikar AM, Lee DM, Hueber W, Robinson WH, Cairns E: Arthritis induced by posttranslationally modified (citrullinated) fibrinogen in DR4-IE transgenic mice. J Exp Med 2008, 205:967-979.

26. Hill JA, Southwood S, Sette A, Jevnikar AM, Bell DA, Cairns E: Cutting edge: the conversion of arginine to citrulline allows for a high-affinity peptide interaction with the rheumatoid arthritis-associated HLA-DRB1*0401 MHC class II molecule. J Immuno/ 2003, 171:538-541.

27. Law SC, Street S, Yu CH, Capini C, Ramnoruth S, Nel HJ, van Gorp E, Hyde C, Lau K, Pahau H, Purcell AW, Thomas R: T-cell autoreactivity to citrullinated autoantigenic peptides in rheumatoid arthritis patients carrying HLADRB1 shared epitope alleles. Arthritis Res Ther 2012, 14:R118.

28. von Delwig A, Locke J, Robinson JH, Ng WF: Response of Th17 cells to a citrullinated arthritogenic aggrecan peptide in patients with rheumatoid arthritis. Arthritis Rheum 2010, 62:143-149.

29. Snir O, Rieck M, Gebe JA, Yue BB, Rawlings CA, Nepom G, Malmström V, Buckner JH: Identification and functional characterization of $\mathrm{T}$ cells reactive to citrullinated vimentin in HLA-DRB1*0401-positive humanized mice and rheumatoid arthritis patients. Arthritis Rheum 2011, 63:2873-2883.

30. Trentham DE, Dynesius-Trentham RA, Orav EJ, Combitchi D, Lorenzo C, Sewell KL, Hafler DA, Weiner HL: Effects of oral administration of type II collagen on rheumatoid arthritis. Science 1993, 261:1727-1730

31. Koffeman EC, Genovese M, Amox D, Keogh E, Santana E, Matteson EL, Kavanaugh A, Molitor JA, Schiff MH, Posever JO, Bathon JM, Kivitz AJ, Samodal R, Belardi F, Dennehey C, van den Broek T, van Wijk F, Zhang X, Zieseniss P, Le T, Prakken BA, Cutter GC, Albani S: Epitope-specific immunotherapy of rheumatoid arthritis: clinical responsiveness occurs with immune deviation and relies on the expression of a cluster of molecules associated with T cell tolerance in a double-blind, placebo-controlled, pilot phase II trial. Arthritis Rheum 2009, 60:3207-3216.

32. Kavanaugh A, Genovese M, Baughman J, Kivitz A, Bulpitt K, Olsen N, Weisman M, Matteson E, Furst D, van Vollenhoven R, Anderson J, Cohen S, Wei N, Meijerink J, Jacobs C, Mocci S: Allele and antigen-specific treatment of rheumatoid arthritis: a double blind, placebo controlled phase 1 trial. J Rheumato/ 2003, 30:449-454

33. Staines NA, Derry CJ, Marinova-Mutafchieva L, Ali N, Davies DH, Murphy JJ: Constraints on the efficacy of mucosal tolerance in treatment of human and animal arthritic diseases. Ann New York Acad Sci 2004, 1029:250-259.

34. Ehrenstein MR, Evans JG, Singh A, Moore S, Warnes G, Isenberg DA, Mauri C: Compromised function of regulatory $T$ cells in rheumatoid arthritis and reversal by anti-TNFa therapy. J Exp Med 2004, 200:277-285.

35. Pettit AR, MacDonald KPA, O'Sullivan B, Thomas R: Differentiated dendritic cells expressing nuclear RelB are predominantly located in rheumatoid synovial tissue perivascular mononuclear cell aggregates. Arthritis Rheum 2000, 43:791-800.

36. Thomas R, Quinn C: Functional differentiation of dendritic cells in rheumatoid arthritis: role of CD86 in the synovium. J Immunol 1996 , 156:3074-3086.

37. Thomas R, Davis LS, Lipsky PE: Rheumatoid synovium is enriched in mature antigen-presenting dendritic cells. J Immuno/ 1994, 152:2613-2623.

38. Scher JU, Ubeda C, Equinda M, Khanin R, Buischi Y, Viale A, Lipuma L, Attur M, Pillinger MH, Weissmann G, Littman DR, Pamer EG, Bretz WA, Abramson SB: Periodontal disease and the oral microbiota in new-onset rheumatoid arthritis. Arthritis Rheum 2012, 64:3083-3094.

39. Lutzky V, Hannawi $S$, Thomas R: Cells of the synovium in rheumatoid arthritis. Dendritic cells. Arthritis Res Ther 2007, 9:219.

40. Kenna TJ, Thomas R, Steptoe RJ: Steady-state dendritic cells expressing cognate antigen terminate memory CD8 ${ }^{+} \mathrm{T}$-cell responses. Blood 2008, 111:2091-2100.

41. Zhang ZY, Lee CS, Lider O, Weiner HL: Suppression of adjuvant arthritis in Lewis rats by oral administration of type II collagen. I Immunol 1990, 145:2489-2493. 
42. Thompson HS, Harper N, Bevan DJ, Staines NA: Suppression of collagen induced arthritis by oral administration of type II collagen: changes in immune and arthritic responses mediated by active peripheral suppression. Autoimmunity 1993, 16:189-199.

43. Min SY, Hwang SY, Park KS, Lee JS, Lee KE, Kim KW, Jung YO, Koh HJ, Do JH, Kim H, Kim HY: Induction of IL-10-producing $\mathrm{CD} 4^{+} \mathrm{CD} 25^{+} \mathrm{T}$ cells in animal model of collagen-induced arthritis by oral administration of type II collagen. Arthritis Res Ther 2004, 6:R213-R219.

44. Billingham ME, Carney S, Butler R, Colston MJ: A mycobacterial 65-kD heat shock protein induces antigen-specific suppression of adjuvant arthritis, but is not itself arthritogenic. J Exp Med 1990, 171:339-344.

45. Jorgensen C, Gedon E, Jaquet C, Sany J: Gastric administration of recombinant $65 \mathrm{kDa}$ heat shock protein delays the severity of type II collagen induced arthritis in mice. J Rheumatol 1998, 25:763-767.

46. Sieper J, Kary S, Sorensen H, Alten R, Eggens U, Huge W, Hiepe F, Kuhne A, Listing J, Ulbrich N, Braun J, Zink A, Mitchison NA: Oral type II collagen treatment in early rheumatoid arthritis. A double-blind, placebocontrolled, randomized trial. Arthritis Rheum 1996, 39:41-51.

47. Barnett ML, Kremer JM, St Clair EW, Clegg DO, Furst D, Weisman M, Fletcher MJ, Chasan-Taber S, Finger E, Morales A, Le CH, Trentham DE: Treatment of rheumatoid arthritis with oral type II collagen. Results of a multicenter, double-blind, placebo-controlled trial. Arthritis Rheum 1998, 41:290-297.

48. McKown KM, Carbone LD, Kaplan SB, Aelion JA, Lohr KM, Cremer MA, Bustillo J, Gonzalez M, Kaeley G, Steere EL, Somes GW, Myers LK, Seyer JM, Kang AH, Postlethwaite AE: Lack of efficacy of oral bovine type II collagen added to existing therapy in rheumatoid arthritis. Arthritis Rheum 1999, 42:1204-1208

49. Puga Yung GL, Le TD, Roord S, Prakken B, Albani S: Heat shock proteins (HSP) for immunotherapy of rheumatoid arthritis (RA). Inflamm Res 2003, 52:443-451

50. Verstraeten A, Sileghem A, Dequeker J: OM-8980 and D-penicillamine in the treatment of rheumatoid arthritis. A 12-month double-blind randomized study. Scand J Rheumatol 1990, 19:422-431.

51. Prakken BJ, Samodal R, Le TD, Giannoni F, Yung GP, Scavulli J, Amox D, Roord S, de Kleer I, Bonnin D, Lanza P, Berry C, Massa M, Billetta R, Albani S: Epitopespecific immunotherapy induces immune deviation of proinflammatory T cells in rheumatoid arthritis. Proc Natl Acad Sci U S A 2004, 101:4228-4233.

52. Koffeman EC, Genovese M, Amox D, Keogh E, Santana E, Matteson EL, Kavanaugh A, Molitor JA, Schiff MH, Posever JO, Bathon JM, Kivitz AJ, Samodal R, Belardi F, Dennehey C, van den Broek T, van Wijk F, Zhang X, Zieseniss P, Le T, Prakken BA, Cutter GC, Albani S: Epitope-specific immunotherapy of rheumatoid arthritis: clinical responsiveness occurs with immune deviation and relies on the expression of a cluster of molecules associated with $T$ cell tolerance in a double-blind, placebo-controlled, pilot phase II trial. Arthritis Rheum 2009, 60:3207-3216.

53. Miles JJ, Douek DC, Price DA: Bias in the a $\beta$ T-cell repertoire: implications for disease pathogenesis and vaccination. Immunol Cell Bio/ 2011, 89:375-387.

54. Williams WV, Fang Q, Demarco D, VonFeldt J, Zurier RB, Weiner DB: Restricted heterogeneity of $\mathrm{T}$ cell receptor transcripts in rheumatoid synovium. J Clin Investig 1992, 90:326-333.

55. Jenkins RN, Nikaein A, Zimmermann A, Meek K, Lipsky PE: T cell receptor V $\beta$ gene bias in rheumatoid arthritis. J Clin Investig 1993, 92:2688-2701.

56. Li Y, Sun GR, Tumang JR, Crow MK, Friedman SM: CDR3 sequence motifs shared by oligoclonal rheumatoid arthritis synovial T cells. Evidence for an antigen-driven response. J Clin Investig 1994, 94:2525-2531.

57. Sun W, Nie H, Li N, Zang YCQ, Zhang D, Feng G, Ni L, Xu R, Prasad S, Robinson RR, Ho W, Sercarz E, Zhang JZ: Skewed T-cell receptor BV14 and BV16 expression and shared CDR3 sequence and common sequence motifs in synovial T cells of rheumatoid arthritis. Genes Immun 2005, 6:248-261.

58. Klarenbeek PL, de Hair MJH, Doorenspleet ME, van Schaik BDC, Esveldt REE, van de Sande MGH, Cantaert T, Gerlag DM, Baeten D, van Kampen AHC, Baas F, Tak PP, de Vries N: Inflamed target tissue provides a specific niche for highly expanded T-cell clones in early human autoimmune disease. Ann Rheum Dis 2012, 71:1088-1093.

59. Cohen IR: Lines of T lymphocytes induce or vaccinate against autoimmune arthritis. Science 1983, 219:56-58.

60. Zang YCQ, Hong J, Rivera VM, Killian J, Zhang JZ: Preferential recognition of TCR hypervariable regions by human anti-idiotypic T cells induced by T cell vaccination. J Immuno/ 2000, 164:4011-4017

61. Correale J, Farez M, Gilmore W: Vaccines for multiple sclerosis: progress to date. CNS Drugs 2008, 22:175-198.

62. Moreland LW, Morgan EE, Adamson TC, 3rd, Fronek Z, Calabrese LH, Cash JM, Markenson JA, Matsumoto AK, Bathon J, Matteson EL, Uramoto KM, Weyand CM, Koopman WJ, Heck LW, Strand V, Diveley JP, Carlo DJ, Nardo CJ, Richieri SP, Brostoff SW: T cell receptor peptide vaccination in rheumatoid arthritis: a placebo-controlled trial using a combination of $\mathrm{V} \beta 3, \mathrm{~V} \beta 14$, and $\mathrm{V} \beta 17$ peptides. Arthritis Rheum 1998, 41:1919-1929.

63. Nishizuka Y, Sakakura T: Thymus and reproduction: sex-linked dysgenesia of the gonad after neonatal thymectomy in mice. Science 1969, 166:753-755.

64. Kojima A, Tanaka-Kojima Y, Sakakura T, Nishizuka Y: Prevention of postthymectomy autoimmune thyroiditis in mice. Lab Invest 1976 34:601-605.

65. Itoh M, Takahashi T, Sakaguchi N, Kuniyasu Y, Shimizu J, Otsuka F, Sakaguchi S: Thymus and autoimmunity: production of $\mathrm{CD} 25^{+} \mathrm{CD} 4^{+}$naturally anergic and suppressive T cells as a key function of the thymus in maintaining immunologic self-tolerance. J Immunol 1999, 162:5317-5326.

66. Sakaguchi S, Sakaguchi N, Shimizu J, Yamazaki S, Sakihama T, Itoh M, Kuniyasu Y, Nomura T, Toda M, Takahashi T: Immunologic tolerance maintained by $\mathrm{CD} 25^{+} \mathrm{CD} 4^{+}$regulatory T cells: their common role in controlling autoimmunity, tumor immunity, and transplantation tolerance. Immunol Rev 2001, 182:18-32.

67. Sakaguchi S, Takahashi T, Yamazaki S, Kuniyasu Y, Itoh M, Sakaguchi N, Shimizu $\mathrm{J}$ : Immunologic self tolerance maintained by T-cell-mediated control of self-reactive T cells: implications for autoimmunity and tumor immunity. Microbes Infect 2001, 3:911-918.

68. McHugh RS, Shevach EM, Thornton AM: Control of organ-specific autoimmunity by immunoregulatory $\mathrm{CD}^{+} \mathrm{CD} 25^{+} \mathrm{T}$ cells. Microbes Infect 2001, 3:919-927.

69. Singh B, Read S, Asseman C, Malmstrom V, Mottet C, Stephens LA, Stepankova R, Tlaskalova H, Powrie F: Control of intestinal inflammation by regulatory T cells. Immunol Rev 2001, 182:190-200.

70. Fehervari Z, Yamaguchi T, Sakaguchi S: The dichotomous role of IL-2: tolerance versus immunity. Trends Immuno/ 2006, 27:109-111.

71. Charbonnier L-M, Han WGH, Quentin J, Huizinga TWJ, Zwerina J, Toes REM, Jorgensen C, Louis-Plence P: Adoptive transfer of IL-10-secreting $\mathrm{CD} 4{ }^{+} \mathrm{CD} 49 \mathrm{~b}^{+}$regulatory $\mathrm{T}$ cells suppresses ongoing arthritis. J Autoimmun 2010, 34:390-399.

72. Morgan ME, Flierman $\mathrm{R}$, van Duivenvoorde LM, Witteveen $H$ J, van EwijkW, van Laar JM, de vries RRP, Toes REM: Effective treatment of collagen-induced arthritis by adoptive transfer of $\mathrm{CD} 25^{+}$regulatory T cells. Arthritis Rheum 2005, 52:2212-2221.

73. Tarbell KV, Petit L, Zuo X, Toy P, Luo X, Mqadmi A, Yang H, Suthanthiran M, Mojsov S, Steinman RM: Dendritic cell-expanded, islet-specific $\mathrm{CD}_{4}{ }^{+} \mathrm{CD} 25^{+} \mathrm{CD}_{22} \mathrm{~L}^{+}$regulatory $T$ cells restore normoglycemia in diabetic NOD mice. J Exp Med 2007, 204:191-201.

74. Putnam AL, Brusko TM, Lee MR, Liu W, Szot GL, Ghosh T, Atkinson MA, Bluestone JA: Expansion of human regulatory T-cells from patients with type 1 diabetes. Diabetes 2009, 58:652-662.

75. Groux H, O'Garra A, Bigler M, Rouleau M, Antonenko S, de Vries JE, Roncarolo MG: A CD4 ${ }^{+}$T-cell subset inhibits antigen-specific T-cell responses and prevents colitis. Nature 1997, 389:737-742.

76. Levings MK, Gregori S, Tresoldi E, Cazzaniga S, Bonini C, Roncarolo MG Differentiation of $\operatorname{Tr} 1$ cells by immature dendritic cells requires IL-10 but not CD25+CD4 ${ }^{+}$Tr cells. Blood 2005, 105:1162-1169.

77. Bacchetta R, de Waal Malefijt R, Yssel H, Abrams J, de Vries JE, Spits $H_{4}$ Roncarolo MG: Host-reactive $\mathrm{CD}^{+}$and $\mathrm{CD}^{+} \mathrm{T}$ cell clones isolated from a human chimera produce IL-5, IL-2, IFN-gamma and granulocyte/ macrophage-colony-stimulating factor but not IL-4. J Immuno/ 1990, 144:902-908.

78. Roncarolo M-G, Gregori S, Lucarelli B, Ciceri F, Bacchetta R: Clinical tolerance in allogeneic hematopoietic stem cell transplantation. Immunol Rev 2011, 241:145-163.

79. Coombes JL, Siddiqui KR, Arancibia-Carcamo CV, Hall J, Sun CM, Belkaid Y, Powrie F: A functionally specialized population of mucosal CD $103^{+} \mathrm{DCs}$ induces Foxp $3^{+}$regulatory T cells via a TGF-beta and retinoic aciddependent mechanism. J Exp Med 2007, 204:1757-1764.

80. Benson MJ, Pino-Lagos K, Rosemblatt M, Noelle RJ: All-trans retinoic acid mediates enhanced $T$ reg cell growth, differentiation, and gut homing in the face of high levels of co-stimulation. J Exp Med 2007, 204:1765-1774.

81. Annacker $\mathrm{O}$, Coombes JL, Malmstrom V, Uhlig HH, Bourne T, JohanssonLindbom B, Agace WW, Parker CM, Powrie F: Essential role for CD103 in the 
T cell-mediated regulation of experimental colitis. J Exp Med 2005, 202:1051-1061.

82. Sun CM, Hall JA, Blank RB, Bouladoux N, Oukka M, Mora JR, Belkaid Y: Small intestine lamina propria dendritic cells promote de novo generation of Foxp3 T reg cells via retinoic acid. J Exp Med 2007, 204:1775-1785

83. Kang SG, Lim HW, Andrisani OM, Broxmeyer HE, Kim CH: Vitamin A metabolites induce gut-homing FoxP3+ regulatory T cells. J Immunol 2007, 179:3724-3733.

84. Schambach F, Schupp M, Lazar MA, Reiner SL: Activation of retinoic acid receptor-alpha favours regulatory T cell induction at the expense of IL-17secreting T helper cell differentiation. Eur J Immunol 2007, 37:2396-2399.

85. Mucida D, Park Y, Kim G, Turovskaya O, Scott I, Kronenberg M, Cheroutre H: Reciprocal TH17 and regulatory T cell differentiation mediated by retinoic acid. Science 2007, 317:256-260.

86. Neumann M, Fries H, Scheicher C, Keikavoussi P, Kolb-Maurer A, Brocker E, Serfling E, Kampgen E: Differential expression of Rel/NF-kappaB and octamer factors is a hallmark of the generation and maturation of dendritic cells. Blood 2000, 95:277-285.

87. Pettit AR, Quinn C, MacDonald KP, Cavanagh LL, Thomas G, Townsend W, Handel $M$, Thomas R: Nuclear localization of RelB is associated with effective antigen-presenting cell function. J Immuno/ 1997, 159:3681-3691.

88. Burkly L, Hession C, Ogata L, Reilly C, Marconi LA, Olson D, Tizard R, Cate R, Lo D: Expression of relB is required for the development of thymic medulla and dendritic cells. Nature 1995, 373:531-536.

89. Weih F, Carrasco D, Durham SK, Barton DS, Rizzo CA, Ryseck RP, Lira SA, Bravo $R$ : Multiorgan inflammation and hematopoietic abnormalities in mice with a targeted disruption of RelB, a member of the NF-kappa B/Rel family. Cell 1995, 80:331-340.

90. Wu L, D'Amico A, Winkel KD, Suter M, Lo D, Shortman K: RelB is essential for the development of myeloid-related CD8 $\mathrm{a}^{-}$dendritic cells but not of lymphoid-related CD8a dendritic cells. Immunity 1998, 9:839-847.

91. O'Sullivan BJ, MacDonald KP, Pettit AR, Thomas R: RelB nuclear translocation regulates $B$ cell $\mathrm{MHC}$ molecule, $\mathrm{CD} 40$ expression, and antigen-presenting cell function. Proc Natl Acad Sci U S A 2000, 97:11421-11426.

92. Pai S, O'Sullivan BJ, Cooper L, Thomas R, Khanna R: RelB nuclear translocation mediated by C-terminal activator regions of Epstein-Barr virus-encoded latent membrane protein 1 and its effect on antigenpresenting function in B cells. J Virol 2002, 76:1914-1921.

93. Cobbold S, Waldmann H: Infectious tolerance. Curr Opin Immuno/ 1998 , 10:518-524

94. Martin E, O'Sullivan BJ, Low P, Thomas R: Antigen-specific suppression of a primed immune response by dendritic cells mediated by regulatory $T$ cells secreting interleukin-10. Immunity 2003, 18:155-167.

95. Li M, Zhang X, Zheng X, Lian D, Zhang ZX, Ge W, Yang J, Vladau C, Suzuki M, Chen D, Zhong R, Garcia B, Jevnikar AM, Min WP: Immune modulation and tolerance induction by RelB-silenced dendritic cells through RNA interference. J Immuno/ 2007, 178:5480-5487.

96. Thompson AG, O'Sullivan BJ, Beamish $H$, Thomas R: T cells signaled by $\mathrm{NF}-\mathrm{KB}$ - dendritic cells are sensitized not anergic to subsequent activation. $\mathrm{J}$ Immunol 2004, 173:1671-1680

97. Martin E, Capini C, Duggan E, Lutzky VP, Stumbles P, Pettit AR, O'Sullivan B, Thomas R: Antigen-specific suppression of established arthritis in mice by dendritic cells deficient in NF-KB. Arthritis Rheum 2007, 56:2255-2266.

98. Thomas R, Street S, Ramnoruth N, Pahau H, Law SC, Brunck M, Hyde C, O'Sullivan BJ, Capini C, Tran A, Ng J, Paul S: Feasibility, safety and clinical effects of a single intradermal administration of autologous tolerising dendritic cells exposed to citrullinated peptides in patients with rheumatoid arthritis [abstract]. Arthritis Rheum 2011, 63.

99. Yoshimura S, Bonderson J, Brennan FM, Foxwell BM, Feldmann M: Role of $\mathrm{NF}-\mathrm{KB}$ in antigen presentation and development of regulatory $\mathrm{T}$ cells elucidated by treatment of dendritic cells with protease inhibitor PSI. Eur J Immunol 2001, 31:1883-1893.
100. Geisel J, Kahl F, Muller M, Wagner H, Kirschning CJ, Autenrieth IB, Frick JS: IL-6 and maturation govern TLR2 and TLR4 induced TLR agonist tolerance and cross-tolerance in dendritic cells. J Immuno/ 2007, 179:5811-5818.

101. Turnquist HR, Raimondi G, Zahorchak AF, Fischer RT, Wang Z, Thomson AW: Rapamycin-conditioned dendritic cells are poor stimulators of allogeneic $\mathrm{CD}^{+} \mathrm{T}$ cells, but enrich for antigen-specific Foxp ${ }^{+} T$ regulatory cells and promote organ transplant tolerance. J Immunol 2007, 178:7018-7031.

102. Dong X, Lutz W, Schroeder TM, Bachman LA, Westendorf JJ, Kumar R, Griffin $M D$ : Regulation of relB in dendritic cells by means of modulated association of vitamin $\mathrm{D}$ receptor and histone deacetylase 3 with the promoter. Proc Natl Acad Sci U S A 2005, 102:16007-16012.

103. Stoop JN, Harry RA, von Delwig A, Isaacs JD, Robinson JH, Hilkens CM: Therapeutic effect of tolerogenic dendritic cells in established collageninduced arthritis is associated with a reduction in Th17 responses. Arthritis Rheum 2010, 62:3656-3665.

104. Harry RA, Anderson AE, Isaacs JD, Hilkens CM: Generation and characterisation of therapeutic tolerogenic dendritic cells for rheumatoid arthritis. Ann Rheumatic Dis 2010, 69:2042-2050

105. Giannoukakis N, Phillips B, Finegold D, Harnaha J, Trucco M: Phase I (safety) study of autologous tolerogenic dendritic cells in type 1 diabetic patients. Diabetes Care 2011, 34:2026-2032.

106. Capini C, Jaturanpinyo M, Chang HI, Mutalik S, McNally A, Street S, Steptoe R, O'Sullivan B, Davies N, Thomas R: Antigen-specific suppression of inflammatory arthritis using liposomes. J Immuno/ 2009, 182:3556-3565.

107. Pack CD, Cestra AE, Min B, Legge KL, Li L, Caprio-Young JC, Bell JJ, Gregg RK, Zaghouani H: Neonatal exposure to antigen primes the immune system to develop responses in various lymphoid organs and promotes bystander regulation of diverse T cell specificities. J Immuno/ 2001, 167:4187-4195.

108. Vanderlugt CL, Miller SD: Epitope spreading in immune-mediated diseases: implications for immunotherapy. Nat Rev Immunol 2002, 2:85-95.

109. Vollers SS, Stern L: Class II major histocompatibility complex tetramer staining: progress, problems, and prospects. Immunology 2008, 123:305-313.

110. Newell EW, Klein LO, Yu W, Davis MM: Simultaneous detection of many T-cell specificities using combinatorial tetramer staining. Nat Meth 2009, 6:497-499.

111. van de Stadt LA, de Koning MHMT, van de Stadt RJ, Wolbink G, Dijkmans BAC, Hamann D, van Schaardenburg D: Development of the anti-citrullinated protein antibody repertoire prior to the onset of rheumatoid arthritis. Arthritis Rheum 2011, 63:3226-3233.

112. Deane KD, O'Donnell CI, Hueber W, Majka DS, Lazar AA, Derber LA, Gilliland WR, Edison JD, Norris JM, Robinson WH, Holers VM: The number of elevated cytokines and chemokines in preclinical seropositive rheumatoid arthritis predicts time to diagnosis in an age-dependent manner. Arthritis Rheum 2010, 62:3161-3172.

113. Berglin E, Padyukov L, Sundin U, Hallmans G, Stenlund H, Van Venrooij WJ, Klareskog L, Dahlqvist SR: A combination of autoantibodies to cyclic citrullinated peptide (CCP) and HLA-DRB1 locus antigens is strongly associated with future onset of rheumatoid arthritis. Arthritis Res Ther 2004, 6:R303-R308.

114. van Gaalen FA, van Aken J, Huizinga TW, Schreuder GM, Breedveld FC, Zanell E, van Venrooij WJ, Verweij CL, Toes RE, de Vries RR: Association between HLA class II genes and autoantibodies to cyclic citrullinated peptides (CCPs) influences the severity of rheumatoid arthritis. Arthritis Rheum 2004, 50:2113-2121.

doi:10.1186/ar4130

Cite this article as: Thomas R: Dendritic cells and the promise of antigen-specific therapy in rheumatoid arthritis. Arthritis Research \& Therapy 2013, 15:204. 